\title{
Construction and characterization of neutralizing antibody fragments for efficient access to V3 epitope
}

Y Maruta

From AIDS Vaccine 2012

Boston, MA, USA. 9-12 September 2012

\section{Background}

The neutralizing antibody against HIV-1 is important for the vaccine development. However, primary isolates of HIV-1 have resistance to antibody neutralization. While a neutralization epitope in V3 is exposed by conformational change of gp120 following CD4-binding, anti-V3 IgG molecules are too large to access V3-epitope. The purpose of our study is to develop Fab and $\mathrm{scFv}$ fragments from the anti-V3 monoclonal neutralizing antibody $5 \mathrm{G} 2$ for efficient access to V3-epitope.

\section{Methods}

RNA was extracted from clonal cells producing 5G2, and cDNA was prepared by reverse transcription. Using primers for variable region of heavy and light chains, the antibody genes were amplified by PCR, and inserted into pComb3X vector. Fab and $\mathrm{scFv}$ were produced in the transformed $\mathrm{E}$. coli by induction with isopropyl- $\beta$ D-thiogalactoside, and purified by nickel chelate chromatography.

\section{Results}

Binding of recombinant 5G2 Fab and scFv to V3 epitope was shown by enzyme-linked immune-sorbent assay against V3 peptide. The flow cytometry analysis using cells expressing HIV-1 Env revealed the higher intensity by smaller antibody fragment, suggesting the increased accessibility of small fragment to V3 epitope. Neutralizing activity of these $5 \mathrm{G} 2$ fragments were observed against both primary HIV-1JR-FLwt and neutralization-sensitive variant, JR-FLL175P. In the case of JR-FLwt, scFv showed a significant improvement of neutralization.

Center for AIDS Research, Kumamoto University, Kumamoto, Japan

\section{Conclusion}

The use of smaller antibody fragments, such as scFv and Fab, may be one strategy to overcome steric constraints that confer neutralization resistance of primary isolates. We are now evaluating an effect of small antibody fragments on neutralization against various primary isolates.

Published: 13 September 2012

doi:10.1186/1742-4690-9-S2-P64

Cite this article as: Maruta: Construction and characterization of neutralizing antibody fragments for efficient access to V3 epitope. Retrovirology 2012 9(Suppl 2):P64.
Submit your next manuscript to BioMed Central and take full advantage of:

- Convenient online submission

- Thorough peer review

- No space constraints or color figure charges

- Immediate publication on acceptance

- Inclusion in PubMed, CAS, Scopus and Google Scholar

- Research which is freely available for redistribution

\section{() BioMed Central}

(C) 2012 Maruta; licensee BioMed Central Ltd. This is an Open Access article distributed under the terms of the Creative Commons Attribution License (http://creativecommons.org/licenses/by/2.0), which permits unrestricted use, distribution, and reproduction in any medium, provided the original work is properly cited. 